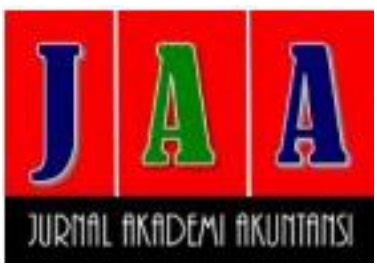

\title{
PENGARUH ASIMETRI INFORMASI DAN LEVERAGE TERHADAP MANAJEMEN LABA PADA PERUSAHAAN PERTAMBANGAN YANG TERDAFTAR DI BURSA EFEK INDONESIA TAHUN 2016-2018
}

\author{
Ayu Apriliani Hidayat*, Ahmad Juanda, Ahmad Waluya Jati \\ Program Studi Akuntansi Fakultas Ekonomi dan Bisnis \\ Universitas Muhammadiyah Malang \\ Jl. Raya Tlogomas No. 246 Malang
}

*Corresponding author : ayuapriliani234@gmail.com

\begin{abstract}
This study aims to examine the relation of information asymmetry and leverage to earnings management in mining companies listed at Indonesian Stock Exchange. Earnings management as the dependent variabel is measured by discretionary accruals. The populations of this study were all mining companies that listed at Indonesian Stock Exchange period 2016-2018. The sample used in this research is about 24 companies through purposive sampling method. The methode of analysis used in this study is panel data regression. The results showed that the information asymmetry hasn't been approved for having significant and negative relation on earnings management. However, leverage have significant and positive relation on earnings management.
\end{abstract}

Keywords : information asymmetry, leverage, earnings management, discretionary accruals

\section{PENDAHULUAN}

Penilaian kinerja suatu perusahaan dapat dilihat dari laporan keuangan. Selain

Diterima : 03 Desember 2019

Direview : 03 Desember 2019

Direvisi : 10 Desember 2019

Diterima : 10 Desember 2019

Artikel ini tersedia di website :

http://ejournal.umm.ac.i d/index.php/jaa 
pada tahun 2015 Toshiba Corporation harus merevisi perhitungan labanya dalam tiga tahun terakhir karena sejak tahun 2008 Toshiba sudah tidak dapat mencapai target keuntungan bisnisnya, sehingga mengakibatkan Toshiba melakukan accounting fraud senilai US\$1,22 Milyar. Akibat dari kasus ini, pada tahun 2015 Toshiba merugi sebesar US\$8 Milyar (Sari, 2017). Di Indonesia kasus praktik manajemen laba terjadi pada PT. Bank Lippo Tbk, kasus ini merupakan kasus yang berhubungan dengan penerbitan laporan keuangan ganda, dimana informasi laporan keuangan pada tanggal 30 September 2002 yang ditujukan kepada publik melalui iklan surat kabar berbeda dengan yang ditujukan kepada Bursa Efek Jakarta. Selain itu, kasus pada PT. Perusahaaan Gas Negara(PGAS) yang terkait dengan pelanggaran prinsip pengungkapan laporan keuangan, pelanggaran yang dilakukan adalah ditundanya pengungkapan informasi tentang penurunan volume gas secara material yang sebenarnya penurunan volume gas ini sudah diketahui oleh pihak manajemen sejak tanggal 12 September 2006 akan tetapi baru dipublikasikan pada bulan Maret 2007, sehingga hal tersebut dapat menyesatkan investor (Sulistiawan dkk, 2011).

Pembahasan manajemen laba berkaitan dengan teori agensi, dimana teori agensi membahas tentang adanya hubungan keagenan antara prinsipal dan agen. Munculnya manajemen laba diakibatkan karena perbedaan kepentingan antara agen dan prinsipal. Sebagai agen, manajer memiliki tanggung jawab untuk mengoptimalkan keuntungan para shareholders selaku prinsipal. Namun, disisi lain manajer juga mempunyai kepentingan untuk memaksimumkan kepentingannya sendiri.

Manajemen laba dapat dipengaruhi oleh beberapa faktor, salah satunya ialah asimetri informasi. Pengertian dari asimetri informasi adalah ketidakseimbangan informasi yang dimiliki oleh pihak manajer atau pihak perusahaan dengan pihak diluar perusahaan atau shareholders. Asimetri informasi dapat terjadi karena pihak manajer lebih mengetahui kondisi perusahaan dan bagaimana kondisi perusahaan untuk kedepannya dibandingkan dengan pihak diluar perusahaan. Jika dikaitkan dengan manajemen laba, semakin sedikit informasi yang diungkapkan oleh manajemen semakin tinggi manajemen laba dan sebaliknya jika semakin banyak informasi yang diungkapkan oleh manajemen maka semakin mudah untuk investor dalam pengambilan keputusan.

Penelitian terdahulu yang dilakukan oleh Suhendah dan Imelda (2012), Dhaneswari dan Widuri (2013), serta Mustikawati dan Cahyonowati (2015) menyatakan bahwa asimetri informasi berpengaruh positif terhadap manajemen laba. Hasil yang berbeda ditemukan pada penelitian Firdaus (2013) dan Setyawan (2017) menyatakan bahwa asimetri informasi berpengaruh secara negatif terhadap manajemen laba.

Leverage merupakan faktor lain yang dapat mempengaruhi manajemen laba. Leverage adalah rasio untuk mengukur seberapa besar pinjaman utang perusahaan dengan menunjukkan beberapa aset yang dapat digunakan untuk menjamin hutang. Ketika perusahaan memiliki tingkat leverage yang tinggi maka perusahaan akan cenderung melakukan praktik manajemen laba karena perusahaan tidak dapat memenuhi kewajibannya secara tepat waktu.

Penelitian terdahulu dari Agusti dan Suryani (2018), Astuti dkk (2018), Naftalia dan Marsono (2013) serta Fatmasari (2016) menyatakan bahwa leverage berpengaruh 
positif terhadap manajemen laba. Sedangkan hasil berbeda ditemukan pada penelitian Jao dan Pagalung (2011) dan Selviani (2017) menyatakan bahwa leverage berpengaruh negatif terhadap manajemen laba.

Dengan adanya perbedaan hasil penelitian terdahulu, maka penting dilakukan untuk penelitian lanjutan agar diperoleh hasil yang berbeda-beda serta lebih baik dari penelitian sebelumnya. Objek yang digunakan dalam penelitian ini adalah perusahaan pertambangan yang terdaftar di Bursa Efek Indonesia tahun 2016-2018. Perusahaan pertambangan dipilih sebagai objek penelitian karena sektor pertambangan berpengaruh terhadap perekonomian negara serta persaingan usaha pertambangan juga semakin meningkat.

\section{PERUMUSAN HIPOTESIS}

Kerangka berfikir pada penelitian ini yaitu menganalisis pengaruh asimetri informasi dan leverage terhadap manajemen laba. Variabel dependen dalam penelitian ini adalah manajemen laba, sedangkan variabel independen dalam penelitian ini adalah asimetri informasi dan leverage.

\section{Pengaruh Asimetri Informasi terhadap Manajemen Laba}

Asimetri Informasi merupakan ketidak seimbangan informasi yang dimiliki perusahaan dengan pihak shareholders. Hal ini dapat terjadi didalam perusahaan akibat pihak manajemen lebih mengetahui keadaan internal perusahaan serta prospek perusahaan kedepannya dibandingkan dengan pihak shareholders. Terjadinya asimetri informasi dapat mempengaruhi tingkat manjemen laba yang bertujuan untuk meningkatkan nilai agar kondisi perusahaan terlihat baik.

Menurut Mustikawati dan Cahyonowati (2015), Dhaneswari dan Widuri (2013) hasil penelitian menunjukkan bahwa asimetri informasi berpengaruh terhadap manajemen laba.

\section{$H_{1}$ : Asimetri informasi berpengaruh terhadap manajemen laba}

\section{Pengaruh Leverage terhadap Manajemen Laba}

Leverage rasio untuk mengukur seberapa besar pinjaman utang perusahaan dengan menunjukkan beberapa aset yang dapat digunakan untuk menjamin hutang. Besarnya tingkat leverage dapat mempengaruhi tingkat manajemen laba. Tingginya tingkat leverage dapat disebabkan oleh kesalahan pengelolaan keuangan perusahaan atau strategi yang digunakan kurang tepat dari pihak manajemen sehingga perusahaan tidak dapat memenuhi kewajibannya secara tepat waktu.. Leverage yang tinggi akan meningkatkan praktik manajemen laba untuk memepertahankan kinerja perusahaan di mata pemegang saham dan publik.

Menurut Agustia dan Suryani (2018) serta Astuti dkk (2017) hasil penelitian menunjukkan bahwa leverage berpengaruh terhadap manajemen laba.

\section{$\mathrm{H}_{2}$ : Leverage berpengaruh terhadap manajemen laba}




\section{METODE PENELITIAN}

Jenis penelitian yang digunakan dalam penelitian ini adalah asosiatif yang bertujuan untuk mengetahui pengaruh antara dua variabel atau lebih. Populasi dalam penelitian ini adalah perusahaan pertambangan yang terdaftar di Bursa Efek Indonesia periode 2016-2018. Purposive sampling adalah metode yang digunakan untuk penentuan sampel dalam penelitian ini. Berikut kriteria sampel dalam penelitian ini :

1. Perusahaan pertambangan yang telah menerbitkan laporan keuangan dan sudah dilakukan audit berturut-turut untuk periode tahun 2016-2018.

2. Perusahaan pertambangan yang menyajikan data yang lengkap mengenai variabel penelitian dari tahun 2016-2018.

Variabel dependen yang digunakan dalam penelitian ini adalah manejemen laba. Manajemen laba dihitung menggunakan discretionary accrual (DACC) yang merupakan perhitungan model Jones modifikasi. Berikut langkah-langkah untuk mencari discretionary accrual (DACC):

1. Menghitung nilai total akrual menggunakan dengan formulasi

TACit $=$ NIit - CFOit

2. Mencari nilai koefisien $\beta_{1}, \beta_{2}$, dan $\beta_{3}$ dengan formulasi

TACit $/$ TAit $-1=\boldsymbol{\beta}_{1}(1 /$ TAit -1$)+\boldsymbol{\beta}_{2}((\Delta$ REVit $-\Delta$ RECit $) /$ TAit -1$\left.)\right)+$ $\boldsymbol{\beta}_{3}($ PPEit/ TAit-1) + git

3. Menghitung Nondiscretionary Accrual (NDACC)

$$
\begin{gathered}
\text { NDACit } \left.=\boldsymbol{\beta}_{1}(1 / \text { TAit }-1)+\boldsymbol{\beta}_{2}((\Delta \text { REVit }-\Delta \text { RECit }) / \text { TAit }-1)\right)+ \\
\boldsymbol{\beta}_{3}(\text { PPEit } / \text { TAit }-1)+\text { eit }
\end{gathered}
$$

4. Menghitung discretionary accrual (DACC)

$$
\text { DACC }=(\text { TAC } / \text { TAit }-1)-\text { NDACC }
$$

Dimana :

TACit = Total akrual perusahaan i pada tahun $\mathrm{t}$

NIit $\quad=$ Laba bersih perusahaan i pada tahun $t$

CFOit $\quad=$ Arus kas operasi perusahaan i pada tahun $t$

TAit-1 = Total aset perusahaan pada akhir tahun $\mathrm{t}-\mathrm{l}$

$\triangle \mathrm{REVit} \quad=$ Perubahan total pendapatan bersih pada tahun $\mathrm{t}$

$\triangle$ RECit $\quad=$ Perubahan total piutang bersih pada tahun $\mathrm{t}$

PPEit $\quad=$ Aset tetap perusahaan $\mathrm{i}$ pada tahun $\mathrm{t}$

NDACC $_{i t}=$ Nondiscretionary Accrual perusahaan i pada tahun $\mathrm{t}$

DACC = Discretoionary Accrual

Untuk variabel independen yang pertama dalam penelitian ini adalah asimetri informasi. Asimetri informasi dihitung menggunakan model teori bid-ask spread yang dihitung menggunakan perhitungan sebagai berikut:

Dimana :

$$
\text { SPREAD }=(\text { ASKit-BIDit }) /\{(\text { ASKit+BIDit }) / 2\} \times 100 \%
$$

$\mathrm{ASK}_{\mathrm{it}}=$ Harga penawaran saham tertinggi perusahaan i yang terjadi pada hari $\mathrm{t}$ (pada tanggal publikasi laporan keuangan) 
$\mathrm{BID}_{\mathrm{it}}=$ Harga permintaan saham terendah perusahaan i yang terjadi pada hari $\mathrm{t}$ (pada tanggal publikasi laporan keuangan)

Variabel independen yang kedua dalam penelitian ini adalah leverage. Dalam penelitian ini leverage dihitung menggunakan debt ratio atau debt to total asset yang diukur menggunakan rumus sebagai berikut:

\section{Debt Ratio $=$ Total Hutang $/$ Total Assets $\times 100 \%$}

Teknik analisis data yang digunakan dalam penelitian ini adalah dengan menggunakan alat analisis Eviews. Di dalam penelitian ini menggunakan metode uji regresi data panel. Uji regresi data panel digunakan untuk mengetahui hubungan antara variabel independen dengan variabel dependen. Regresi data panel diharuskan memilih beberapa model pendekatan yang paling tepat untuk mengestimasi data panel yaitu pendekatan model Common Effect, Fixed Effect, dan Random Effect.

\section{HASIL DAN PEMBAHASAN}

\section{Pendekatan Model Common Effect}

Tabel 1. Hasil Regresi Data Panel Model Common Effect

\begin{tabular}{crrrr}
\hline \hline Variable & Coefficient & Std. Error & t-Statistic & Prob. \\
\hline \hline C & 0.014351 & 0.012198 & 1.176472 & 0.2434 \\
ASY_INF & -0.134380 & 0.150746 & -0.891432 & 0.3758 \\
LEV & 0.018216 & 0.011961 & 1.522915 & 0.1324 \\
\hline \hline R-squared & 0.045050 & Prob(F-statistic) & 0.203857 \\
Adjusted R-squared & 0.017371 & Hannan-Quinn criter. & -2.222242 \\
F-statistic & 1.627563 & Durbin-Watson stat & 1.029984 \\
\hline \hline
\end{tabular}

Berdasarkan hasil tabel 1 diatas diketahui bahwa adjusted $R$-squared atau koefisien determinasi sebesar 0,045 dan nilai Durbin Watson sebesar 1,029984. Dari hasil tersebut masih menggunakan persamaan Ordinary Least Square (OLS), maka perlu ditindak lanjuti lagi dengan cara melakukan uji Chow untuk memilih model common effect atau model fixed effect yang tepat untuk digunakan dalam penelitian ini

\section{Uji Chow}

Uji Chow merupakan uji untuk memilih antara model common effect dan model fixed effect yang tepat digunakan dalam penelitian. Berikut hasil dari uji Chow.

\section{Tabel 2. Hasil Uji Chow}

\begin{tabular}{lrrr}
\hline \hline Effects Test & Statistic & d.f. & Prob. \\
\hline \hline Cross-section F & 2.967645 & $(23,46)$ & 0.0008 \\
Cross-section Chi-square & 65.505501 & 23 & 0.0000
\end{tabular}

$\overline{\text { Berdasarkan tabel } 2 \text { diatas diketahui jika nilai probabilitas }}$ dari Chi-Square sebesar 0,000 yang berarti nilai probabilitas signifikansi lebih kecil dari 0,05 maka $\mathrm{H}_{0}$ diterima sehingga model yang dipilih fixed effect. 


\section{Model Fixed Effect}

Tabel 3. Hasil Regresi Data Panel Model Fixed Effect

\begin{tabular}{lrrrr}
\hline \hline \multicolumn{1}{c}{ Variable } & Coefficient & Std. Error & t-Statistic & Prob. \\
\hline \hline C & 0.009938 & 0.010693 & 0.929439 & 0.3575 \\
ASY_INF & -0.176334 & 0.158475 & -1.112694 & 0.2716 \\
LEV & 0.027642 & 0.011881 & 2.326662 & 0.0244 \\
\hline \hline \multicolumn{4}{c}{ Effects Specification } & \\
\hline \hline Cross-section fixed (dummy variables) & \\
\hline \hline R-squared & 0.615532 & Mean dependent var & 0.021478 \\
Adjusted R-squared & 0.406582 & S.D. dependent var & 0.077261 \\
S.E. of regression & 0.059517 & Akaike info criterion & -2.530916 \\
Sum squared resid & 0.162944 & Schwarz criterion & -1.708787 \\
Log likelihood & 117.1130 & Hannan-Quinn criter. & -2.203624 \\
F-statistic & 2.945837 & Durbin-Watson stat & 2.545122 \\
Prob(F-statistic) & 0.000735 & & \\
\hline \hline
\end{tabular}

Berdasarkan tabel 3 diatas diketahui bahwa nilai adjusted $R$-squared atau koefisien determinasi sebesar 0,6155 dan nilai Durbin Watson sebesar 2,545122.

Model ini hampir sama dengan Ordinary Least Square (OLS), namun diberikan dummy variable pada intersep nya, sehingga diasumsikan bahwa intersep dari unit cross section atau juga time series nya itu berbeda-beda. Kelemahan dari model ini adalah dummy menunjukan ketidakpastian model yg digunakan. Maka untuk mengatasi masalah tersebut, perlu digunakan variable residual yg ada pada model Random Effect. Untuk memilih model yg terbaik antara Fixed Effect dengan Random Effect, maka uji selanjutnya adalah uji hausman.

\section{Uji Hausman}

Uji Hausman merupakan pengujian yang digunakan untuk memilih dan membandingkan antara model fixed effect atau random effect yang paling digunakan dalam penelitian. Berikut hasil uji hausman.

Tabel 4. Hasil Uji Hausman

\begin{tabular}{lccc}
\hline \hline Test Summary & $\begin{array}{c}\text { Chi-Sq. } \\
\text { Statistic }\end{array}$ & Chi-Sq. d.f. & Prob. \\
\hline \hline Cross-section random & 0.747665 & 2 & 0.6881 \\
\hline \hline
\end{tabular}

Dari tabel 4 diatas nilai probabilitas signifikasni menunjukkan nilai sebesar 0,6881 yang berarti nilai lebih besar dari nilai signifikansi 0,05. Sehingga model yang tepat dalam pengujian ini adalah model random effect.

\section{Model Random Effect}

Model ini mengestimasi data panel dimana variabel gangguan mungkin saling berhubungan antar waktu dan antar individu. Keuntungan dari model ini adalah 
menghilangkan heteroskedasitas dan model ini menggunakan teknik Generalized Least Square (GLS). Berikut hasil model random effect:

Tabel 5. Hasil Regresi Data Panel Model RandomEffect

\begin{tabular}{|c|c|c|c|c|}
\hline Variable & Coefficient & Std. Error & $\mathrm{t}$-Statistic & Prob. \\
\hline C & 0.011784 & 0.014514 & 0.811944 & 0.4196 \\
\hline ASY_INF & -0.155360 & 0.141015 & -1.101733 & 0.2744 \\
\hline LEV & 0.023545 & 0.010841 & 2.171728 & 0.0333 \\
\hline \multicolumn{5}{|c|}{ Effects Specification } \\
\hline & & & S.D. & Rho \\
\hline Cross-section random & & & 0.050609 & 0.4196 \\
\hline Idiosyncratic random & & & 0.059517 & 0.5804 \\
\hline \multicolumn{5}{|c|}{ Weighted Statistics } \\
\hline $\mathrm{R}$-squared & 0.081543 & \multicolumn{2}{|c|}{ Mean dependent var } & 0.012065 \\
\hline Adjusted R-squared & 0.054921 & \multicolumn{2}{|c|}{ S.D. dependent var } & 0.060664 \\
\hline S.E. of regression & 0.058974 & \multicolumn{2}{|c|}{ Sum squared resid } & 0.239980 \\
\hline F-statistic & 3.063017 & \multicolumn{2}{|c|}{ Durbin-Watson stat } & 1.726504 \\
\hline Prob(F-statistic) & 0.053152 & & & \\
\hline
\end{tabular}

Berdasarkan tabel 5 diatas diketahui bahwa nilai adjusted $R$-squared atau koefisien determinasi sebesar 0,081 dan nilai Durbin Watson sebesar 1,726504. Inilah model yang terbaik dalam penelitian ini sehingga tidak perlu lagi menggunakan uji asumsi klasik.

\section{Analisis Hasil Regresi Data Panel Model Random Effect}

Berdasarkan tabel 5 berikut hasil regresi data panel model random effect dapat dituliskan dalam bentuk persamaan :

$$
\mathrm{DAC}_{\text {it }}=0,011784-0,155360 \mathrm{ASY}_{\text {it }}+0,023545 \mathrm{LEV}_{\text {it }}
$$

\section{Uji Statistik T}

Berdasarkan tabel 5 dapat disimpulkan jika hasil pengujian uji t untuk variabel

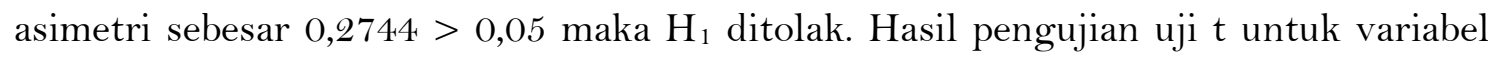

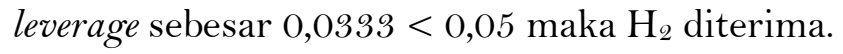

\section{Uji Statistik F}

Berdasarkan tabel 5 dapat disimpulkan jika nilai probabilitas signifikan sebesar 0,053152 yang berarti dapat disimpulkan persamaan regresi dinyatakan signifikan.

\section{Pembahasan}

\section{Pengaruh Asimetri Informasi terhadap Manajemen Laba}

Berdasarkan hasil uji t diperoleh tingkat signifikansi sebesar 0,2744 > 0,05, koefisien regresi sebesar -0,155360 dan uji F sebesar 0,053152 yang artinya asimetri informasi tidak berpengaruh negatif signifikan terhadap manajemen laba. 
Asimetri informasi tidak berpengaruh terhadap manajemen laba dikarenakan informasi yang ada dalam laporan keuangan harus relevan atau berguna untuk pemakai laporan keuangan selain itu, semua informasi yang berkaitan dengan kinerja sebuah perusahaan harus diungkapkan di laporan keuangan serta laporan keuangan harus bersifat netral yang artinya tidak menuruti keinginan dari pihak-pihak tertentu untuk mencapai keuntungan, sehingga laporan keuangan harus mencerminkan kondisi real perusahaan.

\section{Pengaruh Leverage terhadap Manajemen Laba}

Berdasarkan hasil uji t diperoleh tingkat signifikansi sebesar 0,0333<0,05, koefisien regresi sebesar 0,023545 dan uji F sebesar 0,053152 yang berarti leverage berpengaruh positif signifikan terhadap manajemen laba.

Leverage yang tinggi menunjukkan bahwa perusahaan memiliki nilai hutang yang tinggi sehingga hal ini dapat membahayakan perusahaan karena perusahaan akan masuk dalam kategori extreme leverage. Perusahaan yang memiliki rasio leverage yang tinggi akan cenderung melakukan praktik manajemen laba untuk mempertahankan kinerja perusahaan dimata pemegang saham.

\section{SIMPULAN}

Berdasarkan hasil dari analisa data diatas dapat disimpulkan bahwa asimetri informasi tidak berpengaruh negatif signifikan terhadap manajemen laba sedangkan leverage berpengaruh positif signifikan terhadap manajemen laba. Adapun keterbatasan dalam penelitian ini adalah hanya menggunakan dua variabel bebas yaitu asimetri informasi dan leverage serta dalam penelitian ini hanya menggunakan objek pertambangan. Adapun saran untuk penelitian selanjutnya adalah dapat menambah variabel independen yang lain, dapat meneliti pada objek selain pertambangan dan dapat menambah kurun waktu penelitian untuk mendapatkan hasil yang lebih baik.

\section{DAFTAR PUSTAKA}

Agusti, R., \& Pramesti, T. (n.d.). Pengaruh Asimetri Informasi, Ukuran Perusahaan, Kepemilikan Manajerial Terhadap Manajemen Laba.

Agustia, Y. P., \& Suryani, E. (2018). Pengaruh Ukuran Perusahaan, Umur Perusahaan, Leverage dan Profitabilitas terhadap Manajemen Laba (Studi pada Perusahaan Pertambangan yang Terdaftar di Bursa Efek Indonesia Periode 2014-2016).

Almadara, Y. P. (2017). Pengaruh Leverage terhadap Manajemen Laba dengan Corporate Governance sebagai Variabel Moderasi pada Perusahaan Perbankan yang Terdaftar di BEI.

Ardiyanto, M. D., \& Arief, A. (2014). Pengaruh Pengungkapan Corporate Social Responsibility terhadap Manajemen Laba (Studi Kasus pada Perusahaan Non Keuangan dan Jasa yang Terdaftar di Bursa Efek Indonesia tahun 2010-2012.

Astuti dkk. (2017). Pengaruh Ukuran Perusahaan dan Leverage Terhadap Manajemen Laba. 
Azlina, N. (2010). Analisis Faktor yang Mempengaruhi Manajemen Laba. Pekbis Jurnal. Cahyonowati, N., \& Mustikawati, A. (2015). Pengaruh Asimetri Informasi Terhadap Manajemen Laba dengan Ukuran Perusahaan sebagai Variabel Pemoderasi.

Dhaneswari, N., \& Widuri, R. (2013). Pengaruh Asimetri Informasi, Ukuran Perusahaan dan Beban Pajak Tangguhan terhadap Praktik Manajemen Laba di Perusahaan Manufaktur Terdaftar di Bursa Efek Indonesia (BEI) 2010-2012.

Fatmasari, S. (2016). Pengaruh Profitabilitas dan Leverage terhadap Manajemen Laba pada Perusahaan Manufaktur Terdaftar di Bursa Efek Indonesia Tahun 20122014.

Firdaus, I. (2013). Pengaruh Asimetri Informasi dan Captal Adequacy Ratio Terhadap Manajemen Laba.

Firdus, I. (2013). Pengaruh Asimetri Informasi dan Capital Adequacy Ratio Terhadap Manajemen Laba.

Ghozali, I. (2013). Aplikasi Analisis Multivariate dengan Program SPSS.

Herianti, E., \& Suryani, A. (2016). Pengaruh Penggungkapan Tanggung Jawab Sosial Perusahaan terhadap Koefisien Respon Laba dan Manajemen Laba.

Jao, R., \& Pagalung, G. (2011). Corporate Governance, Ukuran Perusahaan, dan Leverage terhadap Manajemen Laba Perusahaan Manufaktur Indonesia.

Komalasari, P. T. (2011). Asimetri Informasi dan Cost of Equity Capital.

Nafatlia, V. C., \& Marsono. (2013). Pengaruh Leverage terhadap Manajemen Laba dengan Corporate Governance sebagai Variabel Pemoderasi.

Nuraina dkk. (n.d.). Pengaruh Ukuran Perusahaan dan Leverage terhadap Manajemen Laba.

Prasojo, F. B. (2017). Pengaruh Manajemen Laba terhadap Corporate Social Responsibility Berbasis Website.

Restuwulan. (2013). Pengaru Asimetri Informasi dan Ukuran Perusahaan terhadap Manajemen Laba.

Sari, K. (2017). Integrity. Retrieved from www.integrity-indonesia.com

Scott, W. R. (2009). Financial Accounting Theory. Inc: USA Prentice Hall.

Selviani, A. H. (2017). Pengaruh Profitabilitas, Leverage, dan Ukuran Perusahaan terhadap Manajemen Laba (Studi Empiris pada Perusahaan Manufaktur yang Terdaftar di Bursa Efek Indonesia Tahun 2014-2016).

Sembiring, C. L. (2017). Manajemen Laba dan Pengungkapan Tanggung Jawab Sosial Perusahaan dengan Komisaris Independen dan Kepemilikan Institusional sebagai Variabel Pemoderasi.

Setyawan, Y. B. (2017). Hubungan Asimetri Informasi dan Ukuran Perusahaan dengan Manajemen Laba.

Sugiyono. (2010). Metode Penelitian Kuantitatif dan Kualitatif $R \Theta^{2} D$.

Suhendah, R., \& Imelda, E. (201 1). Pengaruh Asimetri Informasi, Kinerja Masa Kini dan Kinerja Masa Depan Terhadap Earnings Management pada Perusahaan Manufaktur yang Go Public dari Tahun 2006-2008.

Sulistiawan dkk. (2011). Creative Accounting "Mengungkap Manajemen Laba dan Skandal Akuntansi". Jakarta: Salemba Empat. 
Tyasari, I. (2009). Asimetri Informasi dan Praktik Manajemen Laba pada Perusahaan Manufaktur di Bursa Efek Indonesia.

Wardani, D. K., \& Santi, D. K. (2018). Pengaruh Tax Plannin, Ukuran Perusahaan, Corporate Social Responcibility terhadap Manajemen Laba. 